differences between the control and intervention groups regarding secondary outcomes.

Conclusions FFI and personalized BP regimens improve the rate of adequate BP, especially in patients with a higher risk for inadequate BP. As such, inpatients would benefit from this novel approach for better BP to ultimately improve the quality of colonoscopies.

\section{IDDF2021-ABS-0121 CLINICAL AND SUBCLINICAL CHARACTERISTICS OF ACUTE PERIPANCREATIC FLUID COLLECTIONS IN ACUTE PANCREATITIS}

Anh Tran Ngoc*, Thanh Duong Cong, Nhan Do Hong. Hanoi Medical University Hospital, Vietnam

\subsection{6/gutjnl-2021-IDDF.145}

Background Acute peripancreatic fluid collection is the most frequent complication of acute pancreatitis, 30\% - 50\%.

Objectives To investigate the clinical and subclinical characteristics of acute peripancreatic fluid collections in acute pancreatitis and some factors related to the formation of acute peripancreatic fluid collections

Methods A prospective descriptive study of 117 patients diagnosed with acute pancreatitis with acute peripancreatic fluid collections according to the 2012 revised Atlanta classification at Hanoi Medical University Hospital from August 2018 to June 2021.

Results The mean age of patients in the study group was 42 years old. Ratio male/female: $8 / 1$. The proportion of alcoholic etiology $(60 \%)$ in patients with acute peripancreatic fluid collections was significantly higher compared to other etiologies ( $\mathrm{p}<0.01$ ). Abdominal pain was found in $100 \%$ of patients (IDDF2021-ABS-0121 Figure 1. Clinical symptoms in the group with acute peripancreatic fluid collections). The level of pain according to VAS scale on admission in grade $\mathrm{E}$ was significantly higher, compared in grade D $(5.2 \pm 1.3$ vs. $4.6 \pm$ 1.2, $\mathrm{p}<0.01)$. Abdominal distention, fever, organ failure in grade $\mathrm{E}$ were significantly higher than in grade $\mathrm{D}$, respectively

\begin{tabular}{|c|c|c|c|c|}
\hline Variable & $\begin{array}{l}\text { Total } \\
(\mathrm{N}=117)\end{array}$ & $\begin{array}{l}\text { Grade } D \\
(\mathrm{~N}=61)\end{array}$ & $\begin{array}{l}\text { Grade } E \\
(\mathrm{~N}=56)\end{array}$ & $p$-value \\
\hline Abdominal distention & $82.1 \%$ & $75.4 \%$ & $91.1 \%$ & 0.025 \\
\hline Fever & $38.5 \%$ & $29.5 \%$ & $48.2 \%$ & 0.038 \\
\hline $\begin{array}{l}\text { Abdominal wall } \\
\text { resistance }\end{array}$ & $25.6 \%$ & $19.7 \%$ & $32.1 \%$ & 0.123 \\
\hline Abdominal pain (VAS) & $4.9 \pm 1.3$ & $4.6 \pm 1.2$ & $5.2 \pm 1.3$ & 0.009 \\
\hline CRPhs (mg/dl) & $11.2 \pm 11.8$ & $9.4 \pm 10.1$ & $13.2 \pm 13.2$ & 0.147 \\
\hline Hematocrit (\%) & $44.6 \pm 5.0$ & $43.8 \pm 3.8$ & $45.5 \pm 5.9$ & 0.070 \\
\hline White blood cell (G/L) & $13.6 \pm 4.2$ & $13.2 \pm 4.1$ & $14.0 \pm 4.3$ & 0.301 \\
\hline Calcium (mmoll) & $2.1 \pm 0.2$ & $2.2 \pm 0.1$ & $2.0 \pm 0.3$ & 0.000 \\
\hline Blood urea $(\mathrm{mmol} / \mathrm{l})$ & $4.2 \pm 2.0$ & $4.1 \pm 1.5$ & $4.4 \pm 2.6$ & 0.784 \\
\hline Creatinin $(\mu \mathrm{mol} / \mathrm{l})$ & $70.6 \pm 24.9$ & $71.3 \pm 21.3$ & $69.8 \pm 28.7$ & 0.213 \\
\hline Lactat (mmol/l) & $2.5 \pm 1.5$ & $2.2 \pm 1.1$ & $2.8 \pm 1.7$ & 0.069 \\
\hline LDH (IU/L) & $236.0 \pm 201.0$ & $186.6 \pm 96.7$ & $281.3 \pm 255.8$ & 0.010 \\
\hline Amylase (IU/L) & $565.0 \pm 719.1$ & $501.3 \pm 728.4$ & $629.9 \pm 710.6$ & 0.004 \\
\hline
\end{tabular}

LDH lactate dehydrogenase
$91.1 \%$ vs. $75.9 \%, 48.2 \%$ vs $29.5 \%, 16.1 \%$ vs $4.9 \%$, p < 0.05. (IDDF2021-ABS-0121 Table 1, IDDF2021-ABS-0121 Table 2). Serum calcium levels in grade $E$ was significantly lower than in grade $\mathrm{D}(2.0 \pm 0.3$ vs $2.2 \pm 0.1 \mathrm{mmol} / \mathrm{l}, \mathrm{p}<$ $0.01)$. LDH was significantly higher in grade E, compared to grade $\mathrm{D}, 281.3 \pm 255.8$ vs $186.6 \pm 96.7 \mathrm{IU} / \mathrm{L}, \mathrm{p}<0.05$. (IDDF2021-ABS-0121 Table 1, IDDF2021-ABS-0121 Table 2). SIRS score $\geq 2$ and HAPS $>0$ had high rates of $73.3 \%$ and

\begin{tabular}{|c|c|c|c|c|c|}
\hline \multicolumn{2}{|l|}{ Complications } & \multirow{2}{*}{$\begin{array}{l}\text { Total } \\
(\mathrm{N}=117)\end{array}$} & \multirow{2}{*}{$\begin{array}{l}\text { Grade D } \\
(\mathrm{N}=61) \\
0\end{array}$} & \multirow{2}{*}{$\begin{array}{l}\text { Grade E } \\
(\mathrm{N}=56)\end{array}$} & \multirow[t]{2}{*}{ p-value } \\
\hline $\begin{array}{l}\text { Abdominal } \\
\text { complications }\end{array}$ & Thrombosis & & & & \\
\hline \multirow[t]{3}{*}{ Organ failure } & Total & $12(10.2 \%)$ & $3(4.9 \%)$ & $9(16.1 \%)$ & 0.047 \\
\hline & $\begin{array}{l}\text { Respiratory } \\
\text { failure }\end{array}$ & $10(8.5 \%)$ & $2(3.3 \%)$ & $8(14.3 \%)$ & \\
\hline & Renal failure & $2(1.7 \%)$ & $1(1.6 \%)$ & $1(1.8 \%)$ & \\
\hline
\end{tabular}

Abstract IDDF2021-ABS-0121 Table 3 CT grading of acute peripancreatic fluid collections according to severity

\begin{tabular}{lllll}
\hline Variable & Total & Grade D & Grade E & p-value \\
\hline CRPhs $>15(\mathrm{mg} / \mathrm{dl})$ & $35 / 104$ & $18 / 55$ & $17 / 49$ & 0.832 \\
& $(33.7 \%)$ & $(32.7 \%)$ & $(34.7 \%)$ & \\
SIRS $\geq 2$ & $85 / 116$ & $36 / 61$ & $49 / 55$ & 0.000 \\
& $(73.3 \%)$ & $(59.0 \%)$ & $(89.1)$ & \\
HAPS $>0$ & $98 / 116$ & $48 / 61$ & $50 / 55$ & 0.069 \\
& $(84.5 \%)$ & $(78.7 \%)$ & $(90.9 \%)$ & \\
BISAP $\geq 3$ & $5 / 116$ & $2 / 61$ & $3 / 55$ & 0.667 \\
& $(4.3 \%)$ & $(3.3 \%)$ & $(5.5 \%)$ & \\
JSS $\geq 3$ & $19 / 70$ & $7 / 31$ & $12 / 39$ & 0.444 \\
& $(27.1 \%)$ & $(22.6 \%)$ & $(30.8 \%)$ & \\
\hline
\end{tabular}

SIRS systemic inflammatory response syndrome, HAPS harmless acute pancreatitis score, BISAP bedside index for severity in acute pancreatitis, JSS Japanese severity score

Abstract IDDF2021-ABS-0121 Table 4 Frequency of detecting acute peripancreatic fluid collections on ultrasound and on CT

\begin{tabular}{|c|c|c|c|c|}
\hline \multirow[b]{2}{*}{ Location } & \multicolumn{2}{|c|}{ Ultrasound $(\mathrm{N}=71)$} & \multicolumn{2}{|l|}{$\mathrm{CT}(\mathrm{N}=117)$} \\
\hline & Frequency & Percentage (\%) & Frequency & Percentage (\%) \\
\hline $\begin{array}{l}\text { Around the } \\
\text { pancreas }\end{array}$ & 55 & 77.5 & 113 & 96.6 \\
\hline $\begin{array}{l}\text { Left anterior } \\
\text { pararenal space }\end{array}$ & 17 & 23.9 & 69 & 59 \\
\hline $\begin{array}{l}\text { Right anterior } \\
\text { pararenal space }\end{array}$ & 12 & 16.9 & 41 & 35 \\
\hline Hapatorenal recess & 11 & 15.5 & 6 & 5.1 \\
\hline Splenic hilum & 16 & 22.5 & 25 & 21.4 \\
\hline $\begin{array}{l}\text { Right paracolic } \\
\text { gutter }\end{array}$ & 17 & 23.9 & 38 & 32.5 \\
\hline Left paracolic gutter & 17 & 23.9 & 50 & 42.7 \\
\hline Mesenteric root & 6 & 8.5 & 18 & 15.4 \\
\hline Pouch of douglas & 22 & 31 & 35 & 29.9 \\
\hline Omental bursa & 1 & 1.4 & 7 & 6 \\
\hline
\end{tabular}


Abstract IDDF2021-ABS-0121 Table 5 Logistic regression multivariate of risk factors for the degree of acute peripancreatic fluid collections

\begin{tabular}{lllll}
\hline Variable & p-value & B & Exp (B) & $95 \% \mathrm{Cl}$ \\
\hline Calcium & 0.001 & -6.61 & 0.001 & $0.000-0.063$ \\
SIRS $\geq 2$ & 0.026 & 1.34 & 3.819 & $1.177-12.392$ \\
\hline
\end{tabular}

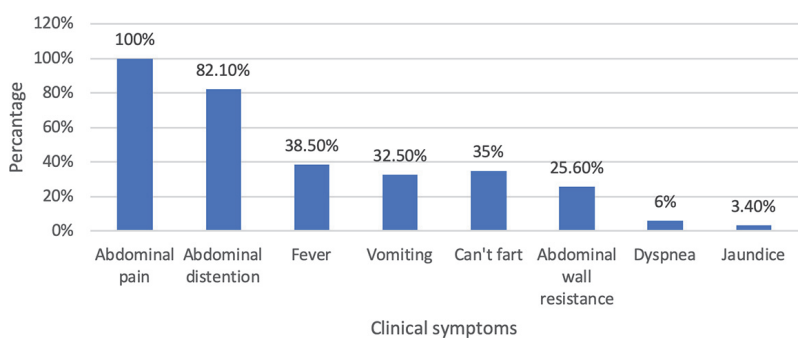

Abstract IDDF2021-ABS-0121 Figure 1

$84.5 \%$, respectively. SIRS score $\geq 2$ in grade $\mathrm{E}$ was significantly higher than in grade D $(89.1 \%$ vs $59.0 \%, \mathrm{p}<0.01)$. (IDDF2021-ABS-0121 Table 3).

Conclusions Alcohol was the most common etiology. Hypocalcemia and SIRS score $\geq 2$ correlated significantly with the occurrence of more acute peripancreatic fluid collections.

\section{IDDF2021-ABS-0124 PREDICTORS OF COMPLICATIONS AND WEIGHT LOSS FOLLOWING INTRA GASTRIC BALLOON INSERTION}

Adnan Alzanbagi*, Abdulaziz Tashkandi, Laeeque Ahmed, Mohammed Khan, Ishtiaque Ahmed, Mahmoud Eliouny, Zaffar Malik, Mohammed Hefny, Mohammed Shariff. King Abdullah Medical City Makkah, Saudi Arabia

\subsection{6/gutjnl-2021-IDDF.146}

Background Obesity is a major global health issue and to address this, multiple weight reduction strategies are emerging. Intragastric balloon (IGB) insertion has shown to be an effective option. However, it is associated with adverse events and weight loss is variable. Hence, the aim of this study is to identify factors associated with weight loss and complications following insertion of IGB.

Methods Retrospective analysis of the complications and weight loss of the patients who had IGB inserted at King Abdullah Medical City, Makkah, a tertiary referral center for Bariatric surgery.

Results Of the 72 patients who had IGB inserted 24 (66.7\%) developed an adverse event, including 5 early removals within 2 weeks. In multivariate stepwise backward logistic regression, female gender was identified as the only predictor of adverse event $(\mathrm{P}=0.009$; odds ratio $0.24795 \%$ confidence interval 0.086 - 0.711). The most common complication was abdominal pain occurring in 15 patients (21\%). Data at 6 months follow-up was available in 67 patients with a mean percentage of excess body weight loss of $17.47 \% \pm 14.21 \%$ with a reduction of BMI of $6.33 \mathrm{~kg} / \mathrm{m}^{2}$. On a multiple regression model, weight loss at 3 months and asthma were significantly correlated with the percentage of excess weight loss $(\mathrm{P}<0.001$ and $\mathrm{P}=0.04$, respectively)
Conclusions In this cohort, the gender of the patients was associated with complications and weight loss at 3 months and asthma predicted the final weight loss.

\section{IDDF2021-ABS-0125 EVIDENCE OF OBJECTIVE ENDOSCOPIC GASTRO ESOPHAGEAL REFLUX POST SLEEVE GASTRECTOMY}

${ }^{1}$ Adnan Alzanbagi*, ${ }^{1}$ Laeeque Ahmed, ${ }^{2}$ Mohammed Alharbi, ${ }^{2}$ Abdulaziz Alzahrani, ${ }^{1}$ Mohammed Khan, 'Zaffar Malik. ${ }^{1}$ King Abdullah Medical City Makkah, Saudi Arabia; ${ }^{2}$ Umm Al Qura University Makkah, Saudi Arabia

\subsection{6/gutjnl-2021-IDDF.147}

Background Sleeve Gastrectomy (SG) is a popular bariatric surgery but its link to gastroesophageal reflux (GERD) is a concern as it's associated with Barrett's esophagus (BE). However, the development of GERD following SG is far from clear. Hence, the aim of this study was to look objectively for endoscopic esophagitis (EE) post SG.

Methods The hospital record of all patients who had post SG endoscopy were reviewed retrospectively. Demographics, comorbidities, medications used, endoscopic findings and helicobacter pylori status were recorded

Results 155 of the 169 patients who had a gastroscopy post SG were included, 14 were excluded, as there were done immediately post SG. Median age of patients was 35 years (range 18-65) with 59\% (92) females and 48\% (74) had hypertension, diabetes mellitus and/or hyperlipidemia. The median post SG endoscopy interval was 16 months (range $7-$ 33). EE was detected in 23\% (36) with $64 \%, 31 \%$ and $5 \%$ having grade $\mathrm{A}, \mathrm{B}$ and $\mathrm{C}$ respectively. None had hiatus hernia and one of them had a $5 \mathrm{~cm}$ Barrett's esophagus (BE). In addition, 26 patients had endoscopy prior to SG of which $15 \%$ (4) had esophagitis post SG and none had esophagitis prior to SG. 19\% (30) were positive for helicobacter pylori (HP) and $23 \%$ of these had esophagitis. Compared to those without HP, the prevalence of esophagitis was not significantly different $(\mathrm{P}$ $=1.00$ ).

Conclusions Endoscopic esophagitis was prevalent in nearly a quarter of our study population. The development of EE may be denovo with the potential to evolve into $\mathrm{BE}$.

\section{IDDF2021-ABS-0127 ASSOCIATION OF HELICOBACTER PYLORI WITH OBESITY IN THE WESTERN POPULATION OF KINGDOM OF SAUDI ARABIA}

${ }^{1}$ Adnan Alzanbagi*, ${ }^{1}$ Laeeque Ahmed, ${ }^{1}$ Sawsan Khan, ${ }^{2}$ Saud Algethami, ${ }^{2}$ Musab Alhumaidi, ${ }^{2}$ Wafaa Alharbi, ${ }^{1}$ Mahmoud Eliouny, ${ }^{1}$ Mohammed Shariff. ${ }^{1}$ King Abdullah Medical City Makkah, Saudi Arabia; ${ }^{2}$ Umm Al Qura University Makkah, Saudi Arabia

\subsection{6/gutjnl-2021-IDDF.148}

Background The prevalence of Helicobacter pylori (HP) in obese patients is conflicting with studies showing a very wide range from $8.7 \%$ to $86 \%$. Hence, the aim of this study was to confirm the prevalence of histologically proven HP in obese patients.

Methods Obese (body mass index (BMI) $\geq 30$, cases) patients who had endoscopy and biopsy for HP in King Abdullah Medical Center (KAMC), Makkah were identified from the 